\title{
Relations between winter atmospheric circulation and annual streamflow in the western United States
}

\author{
Gregory J. McCabe, Jr* \\ U.S. Geological Survey, Denver Federal Center, MS 412, Denver, Colorado 80225, USA
}

\begin{abstract}
Winter mean 700 millibar $(700 \mathrm{mb}$ ) height anomalies, representing the average atmospheric circulation during the snow season, were compared with annual streamflow measured at 140 stream gauges in the western United States. Correlation analysis was used to identify relations between winter mean atmospheric circulation and annual streamflow, and to quantify the degree to which the temporal variability in annual streamflow can be attributed to variations in winter mean atmospheric circulation. Results indicate that winter mean $700 \mathrm{mb}$ height anomalies account for a statistically significant portion of the temporal variability in annual streamflow in the western United States. In general, above-average annual streamflow is associated with negative winter mean $700 \mathrm{mb}$ height anomalies over the eastern North Pacific Ocean and/or the western United States. These anomalies are indicative of anomalous cyclonic circulation which is associated with an anomalous flow of moist air from the eastern North Pacific Ocean into the western United States that increases winter preclpitation and snowpack accumulations, and subsequently streamflow. Below-average annual streamflow is associated with positive $700 \mathrm{mb}$ height anomalies over the eastern North Pacific Ocean and/or the western United States. These positive anomalies indicate anomalous anticyclonic circulation which prevents the intrusion of moist air from the eastern North Pacific Ocean into the western. United States, increases subsidence, decreases winter precipitation, and results in decreased streamflow. Results also indicate that long-term trends in annual streamflow are related to long-term trends in winter mean $700 \mathrm{mb}$ height anomalies.
\end{abstract}

KEY WORDS: Streamflow Western United States A Atmospheric circulation

\section{INTRODUCTION}

Streamflow in many of the watersheds in the western United States is primarily derived from snowmelt, thus snowpack accumulations are useful to forecast peak and total annual streamflow (WMO 1970, Gray \& Male 1981). Scientists have estimated that increasing concentrations of atmospheric carbon dioxide and other 'greenhouse gases' may cause global warming and changes in temporal and spatial distributions of precipitation (Gammon et al. 1985, Bolin 1986, Lins et al. 1988). There is concern that global warming may adversely affect snowpack accumulations in the western United States and therefore have a negative effect on water supply (Gleick 1987, Lettenmaier \& Sheer 1991).

·E-mail address: gmccabe@climate1.cr.usgs.gov
Although general circulation models (GCMs) are able to adequately reproduce the general temporal and spatial distributions of surface climate variables on a global scale, regional-scale climate simulations often vary markedly from observed values (Grotch \& MacCraken 1990, Legates \& Willmott 1992, Willmott \& Legates 1993). Additionally, due to an inadequate representation of topography in most GCMs, even greater uncertainty is introduced into GCM estimates of surface climate (especially precipitation) in mountainous areas, including the western United States.

Recent research suggests that GCM simulations of synoptic-scale weather patterns are more reliable than GCM simulations of surface climatic variables (e.g. temperature or precipitation) because weather patterns are of a spatial scale that is compatible with the spatial resolution of most GCMs (Hay et al. 1992, Hewitson \& Crane 1992, McCabe \& Legates 1992). 
Empirical relations between atmospheric circulation and surface climatic variables may be useful with GCM estimates of future atmospheric circulation to provide more reliable estimates of future surface climatic conditions (Yamal \& Leathers 1988, Hewitson \& Crane 1993)

Global atmospheric circulation can be described by negative and positive atmospheric pressure anomalies which have spatial dimensions of several hundreds to thousands of kilometers (Madden 1979, Cayan \& Peterson 1989). It is often possible to correlate these anomalies with surface weather phenomena (Namias 1975, 1981, Wallace \& Gutzler 1981, Blackmon et al. 1984, Knox \& Lawford 1990). Variations in atmospheric circulation have been found to affect both temporal and spatial variations in temperature and precipitation (Muller \& Wax 1977, Knox 1984, Knox \& Lawford 1990, Cayan et al. 1991). For example, systematic deviations in atmospheric circulation over the eastern North Pacific Ocean and the western United States lead to precipitation anomalies over the western United States (Cayan \& Peterson 1989). Some researchers have found that a statistically significant portion of seasonal precipitation variability can be explained by timeaveraged atmospheric circulation anomalies (Klein 1953, Walsh et al. 1982, Weare \& Hoeschele 1983, Cayan \& Roads 1984, Klein \& Bloom 1987, McCabe 1994).

McCabe \& Legates (in press) identified statistically significant and physically meaningful relations between winter mean $700 \mathrm{mb}$ height anomalies and April 1 snowpack accumulations in the western United States. They found that April 1 snowpack accumulations measured at $97 \%$ of 311 snowcourse stations analyzed were significantly correlated with winter mean $700 \mathrm{mb}$ height anomalies at a $99 \%$ confidence level. Because many of the river basins in the western United States are dominated by snowmelt processes, winter mean atmospheric circulation affecting snowpack accumulations may be useful to estimate annual streamflow in the western United States.

There have been numerous studies that have examined the relations between atmospheric circulation and precipitation (Stidd 1954, Klein 1963, Klein et al. 1965, Cayan \& Roads 1984, Klein \& Bloom 1987, Knox \& Lawford 1990, Cayan et al. 1991, Leathers et al. 1991. Dettinger \& Cayan 1992, McCabe 1994, McCabe \& Legates in press), but there have only been a few studies that have examined the relations between atmospheric circulation and streamflow. In the western United States, streamflow is possibly a more important hydroclimatic variable to study than is precipitation because (1) streamflow is usable water, and (2) streamflow includes precipitation that occurs at high elevations where little or no measurement takes place, but where the input of water is often the greatest (Cayan \& Peterson 1989). Cayan \& Peterson (1989) examined the relations between atmospheric circulation and December through August streamflow at 29 stream gauging stations in the western United States. They identified significant correlations between December through August streamflow and winter mean sea-level pressures. Cayan \& Perterson (1989) also examined the relations between streamflow in the western United States and atmospheric circulation indices, such as the Southern Oscillation Index (SOI) and the Pacific North American (PNA) index. They showed that December through August streamflow in the western United States was significantly correlated with the winter mean SOI and PNA indices. Similarly, Redmond \& Koch (1991) and Kahya \& Dracup (1993) found strong relations between streamflow in the western United States and the SOI.

The objective of this study was to identify relations between winter mean atmospheric circulation and annual streamflow in the western United States that can be used with GCM simulations of future atmospheric circulation to estimate future annual streamflow in the western United States.

\section{METHODS}

Streamflow and atmospheric circulation data. Monthly streamflow data used in this study were measured at 140 stream gauges in the western United States (Fig. 1). The data were obtained from the Hydro-Climatic Data Network (HCDN) published by the U.S. Geological Survey (Slack \& Landwehr 1992).

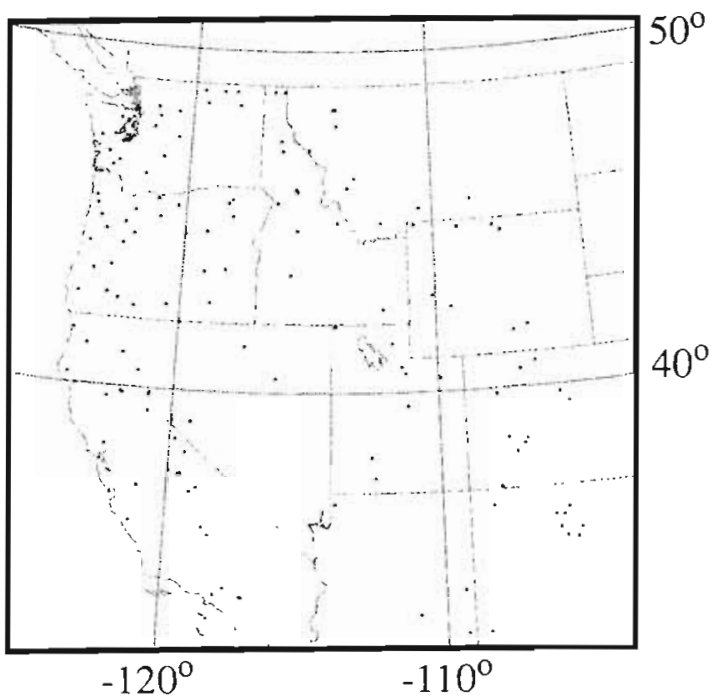

Fig. 1. Locations of stream gauges in the western United States used in this study 
The streamflow records included in the HCDN are from measurements made on unregulated and unimpaired rivers. Thus, the HCDN streamflows are natural. The monthly streamflow data were used to compute total annual streamflow for water years 1948 through 1987 (40 yr).

Height anomalies of the $700 \mathrm{mb}$ level (in $\mathrm{m}$ ) were used to represent atmospheric circulation. The $700 \mathrm{mb}$ atmospheric pressure surface is generally about $3 \mathrm{~km}$ above sea-level, and provides a good representation of mid-tropospheric atmospheric circulation (Dettinger \& Cayan 1992). In addition, several studies have indicated that the $700 \mathrm{mb}$ level is useful in identifying relations between atmospheric circulation and precipitation (Stidd 1954, Klein 1963, Klein \& Bloom 1987, Knox \& Lawford 1990, Cayan et al. 1991). The $700 \mathrm{mb}$ height anomaly values were computed from the gridded atmospheric pressure data produced by the National Oceanic and Atmospheric Administration (NOAA) Climate Analysis Center (CAC) by subtracting the 1950 to 1979 long-term mean $700 \mathrm{mb}$ height for each day from the observed daily $700 \mathrm{mb}$ heights from January 1947 through June 1988 (anomalies obtained from Dan Cayan, Scripps Institute of Oceanography). The $700 \mathrm{mb}$ height anomalies from $20^{\circ}$ to $70^{\circ} \mathrm{N}$ and from $180^{\circ}$ to $90^{\circ} \mathrm{W}$ (encompassing 105 grid points from the $\mathrm{CAC}$ analysis) were used to represent the atmospheric circulation affecting the western United States (Fig. 2). Daily $700 \mathrm{mb}$ height anomalies from November through March were averaged to produce winter mean $700 \mathrm{mb}$ height anomalies for the winters of $1947-48$ through 1986-87 for comparison with the annual streamflow data. Winter mean $700 \mathrm{mb}$ height anomalies averaged for the months of November through March were chosen for comparison with the annual streamflow data because it is primarily during these months that snowpack accumulations develop that eventually become streamflow through snowmelt in many of the river basins in the western United States (McCabe 1994, McCabe \& Legates in press). In addition, $700 \mathrm{mb}$ height anomalies averaged for the months of November through March significantly influence snowpack accumulations in the western United States (McCabe 1994, McCabe \& Legates in press).

Data analysis. Because of the large number of stream gauges included in this study and because previous studies have identified areas in the western United States where annual streamflow is spatially covariant (Cayan \& Peterson 1989), the annual streamflow measured at the 140 stream gauges was subjected to a cluster analysis to identify groups of stream gauges with intercorrelated annual streamflow. The cluster analysis used was a hierarchical average-linkage clustering method. The clustering was based on correlations between time series of annual streamflow measured at each stream gauge (additional details of the clustering procedure are given in 'Results'). Average annual streamflow then was calculated for each cluster and these averages were compared with winter mean $700 \mathrm{mb}$ height anomalies to identify relations between winter mean atmospheric circulation and annual streamflow in the western United States.

Stidd (1954) and Klein (1963) examined relations between atmospheric circulation and precipitation by using maps (fields) of linear correlations between precipitation at specific locations and gridded values of $700 \mathrm{mb}$ height anomalies. These correlation fields are temporal correlations. In such fields, lines of equal correlation are analogous to lines of equal $700 \mathrm{mb}$ height anomalies associated with extreme precipitation (Stidd 1954, Klein 1963). Based on this analogy, relations between $700 \mathrm{mb}$ height anomalies and surface climatic or hydrologic variables at a specific location can be determined. Stidd (1954) indicated that evaluating relations between atmospheric circulation and surface climatic variables using correlation fields has an advantage over techniques that use atmosphericprossure composites becaúse cunteldion rields use aỉ of the available data and account for spatial variations in the standard deviations of atmospheric pressure. Using this approach, Klein \& Bloom (1987) found significant linear relations between $700 \mathrm{mb}$ height anomalies and precipitation. They concluded that the

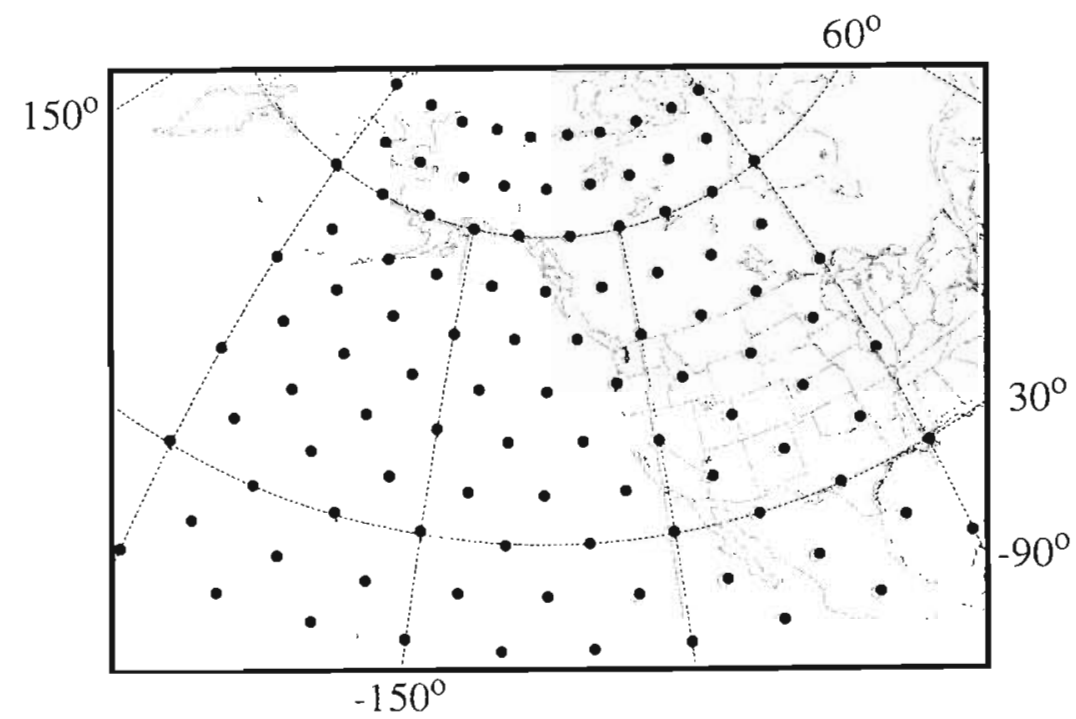

Fig. 2. Climate Analysis Center (CAC) grid points from which winter mean $700 \mathrm{mb}$ height anomaly data were obtained 
assumption of a linear relation between monthly mean $700 \mathrm{mb}$ height anomalies and monthly precipitation was useful for estimating monthly precipitation totals and the frequency of precipitation within a month. They found that at least $42 \%$ of the variability in winter precipitation nationwide and at least $45 \%$ of the variability in the frequency of winter precipitation events nationwide can be explained by variations in $700 \mathrm{mb}$ height anomalies.

In this study, correlations between gridded winter mean $700 \mathrm{mb}$ height anomalies and cluster-average annual streamflow are computed for the water years 1948 through 1987. Following the method of Stidd (1954) and Klein (1963), lines of equal correlation can be interpreted as being analogous to lines of equal $700 \mathrm{mb}$ height anomalies. Thus, in this study, for large values of annual streamflow (i.e. above-average annual streamflow), areas of negative correlations are interpreted as negative $700 \mathrm{mb}$ height anomalies (indicating anomalous cyclonic circulation), and areas of positive correlations are interpreted as positive $700 \mathrm{mb}$ height anomalies (indicating anomalous anticyclonic circulation). For small values of annual streamflow (i.e. below-average annual streamflow), the inverse of these interpretations is used.

\section{RESULTS AND DISCUSSION}

The cluster analysis of annual streamflow measured at the 140 stream gauges resulted in 7 clusters. Fig. 3 illustrates the similarity index computed for 20 to 1 clusters. In any classification procedure the desired

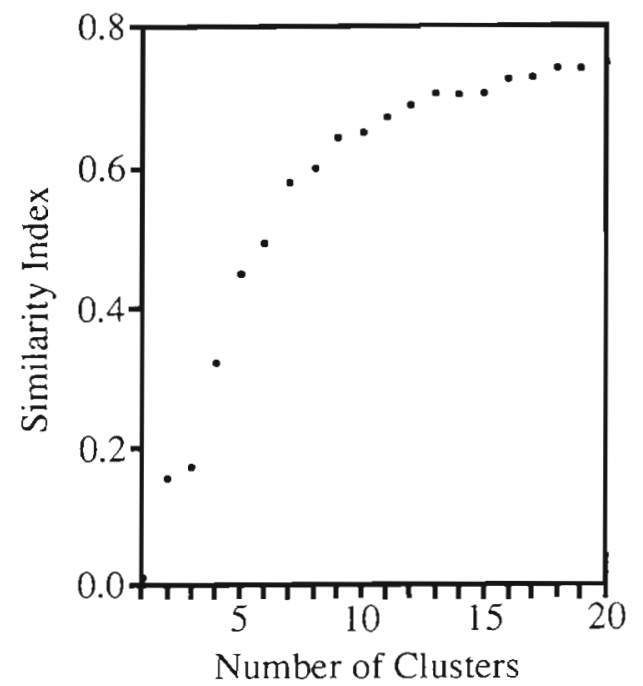

Fig. 3. Comparison of similarity index values for 20 to 1 clusters resulting from a cluster analysis of annual streamflow measured at 140 stream gauges in the western United States result is to obtain the minimum number of clusters necessary to represent the data without a great loss of information. The similarity index decreases as the number of clusters decreases because of the joining of clusters that are dissimilar. When 2 strongly dissimilar clusters are joined the decrease in the similarity index is large and indicates a large loss of information. Fig. 3 illustrates a relatively constant decrease in the similarity index until the decrease of clusters from 7 to 6 . When the number of clusters decreased from 7 to $6 \mathrm{a}$ relatively large decrease in the similarity index occurred indicating a relatively large loss of information. Thus, 7 clusters was chosen as the solution of the clustering process.

Because hierarchical clustering methods can include observations in one cluster early in the clustering process that better fit into another cluster, an additional step was used to improve the clustering of the stream gauges. This step involved the correlation of the time series of annual streamflow at each stream gauge with the time series for each cluster. Each stream gauge was ultimately assigned to the cluster with which it is most highly correlated. An additional requirement was that a stream gauge was only classified if the cluster-average annual streamflow of one of the clusters explained at least $50 \%$ of the variability in the annual streamflow for that stream gauge. This requirement increased the likelihood of reliable clusters, but also resulted in the non-inclusion of some stream gauges into clusters.

The final results of the clustering procedure produced 7 clusters that included 122 of the 140 stream gauges analyzed. Fig. 4 illustrates the cluster assignment for each of the 140 stream gauges. Each cluster exhibits a large amount of spatial coherence which reflects the reliability of the clusters. Cluster $A_{\text {, the }}$ largest cluster, included 43 stations (31\%) located in the northwestern United States, primarily in Washington and western Oregon. Cluster B included 22 stream gauges $(16 \%)$ primarily located in eastern Oregon and northern California. Cluster $\mathrm{C}$ included 20 stream gauges $(14 \%)$ located in the east-central western United States. Cluster D included 19 stream gauges $(14 \%)$ located in southern California and in parts of Nevada. Cluster E included 12 stations (9\%) primarily located in New Mexico and Arizona. Cluster $F$ included 4 stations ( $3 \%$ ) located in southern Montana, and cluster $\mathrm{G}$, the smallest cluster, included only 2 stream gauges $(1 \%)$ located in northern Wyoming. Eighteen stream gauges $(13 \%)$ were unclassified. Clusters A, B, C, D, and E accounted for $83 \%$ of the 140 stream gauges analyzed and $95 \%$ of the 122 stream gauges that were grouped into clusters, thus these clusters are the focus of the remainder of the paper. 


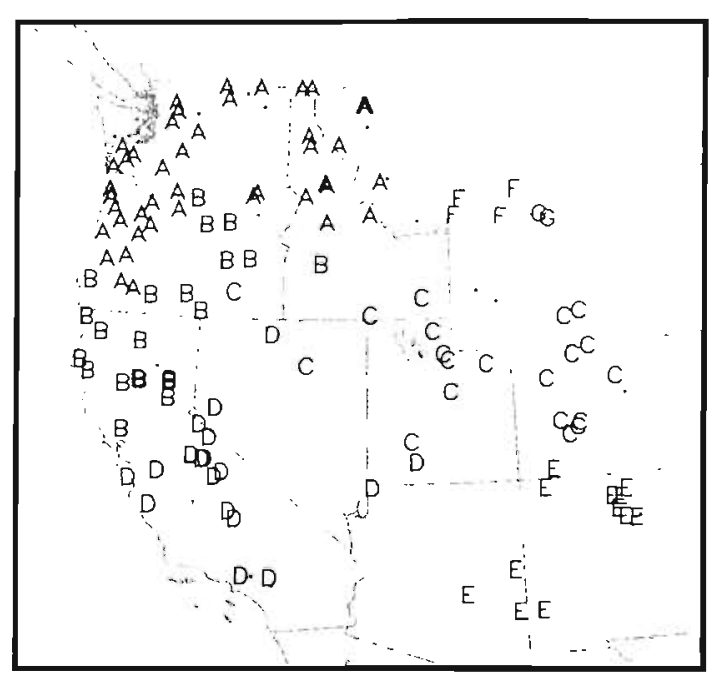

Fig. 4. Locations of stream gauges included in each of 7 clusters (A to $F$ ) of intercorrelated streamflow. Dots indicate stream gauges that were unclassified height anomalies over western Canada The anomalous anticyclonic circulation over western Canada prevents the intiusion of molst alr from the eastern North Pacific Ocean into the northwestern United States, and thus decreases winter precipitation.

The correlation field for cluster $B$ indicates that above-average annual streamflow for the stream gauges located in northern California and eastern Oregon is assoclated with negative winter mean $700 \mathrm{mb}$ height anomalies centered over the eastern North Pacific Ocean and the northwestern coast of the United States (Fig. 5B). The negative anomalles indicate an anomalous southwesterly flow of moist air from the eastern North Pacific Ocean into the central-western coast of the United States.

The correlation field for cluster $C$ indicates that above-average annual streamflow in the east-central western United States is associated with negative winter mean $700 \mathrm{mb}$ height anomalies that extend from the eastern North Pacific Ocean into the western

Average values of annual streamflow were computed for each cluster and for each of the 40 winters analyzed. These average values then were correlated with the gridded winter mean $700 \mathrm{mb}$ height anomalies. The correlation fields for each cluster indicate large areas of correlations that are statistically significant at a $99 \%$ confidence level. Results of these correlations indicate that aboveaverage annual streamflow for the stream gauges included in cluster $A$ is associated with negative winter mean $700 \mathrm{mb}$ height anomalies centered over western Canada and positive anomalies over the eastern North Pacific Ocean (Fig. 5A). The negative anomalies centered over western Canada indicate increased storminess and an anomalous flow of moist air from the eastern North Pacific Ocean into the northwestern United States which increases winter precipitation and subsequent streamflow. In contrast, the negative of the correlation field for cluster $\mathrm{A}$ indicates that below-average annual streamflow in the northwestern United States is associated with positive winter mean $700 \mathrm{mb}$

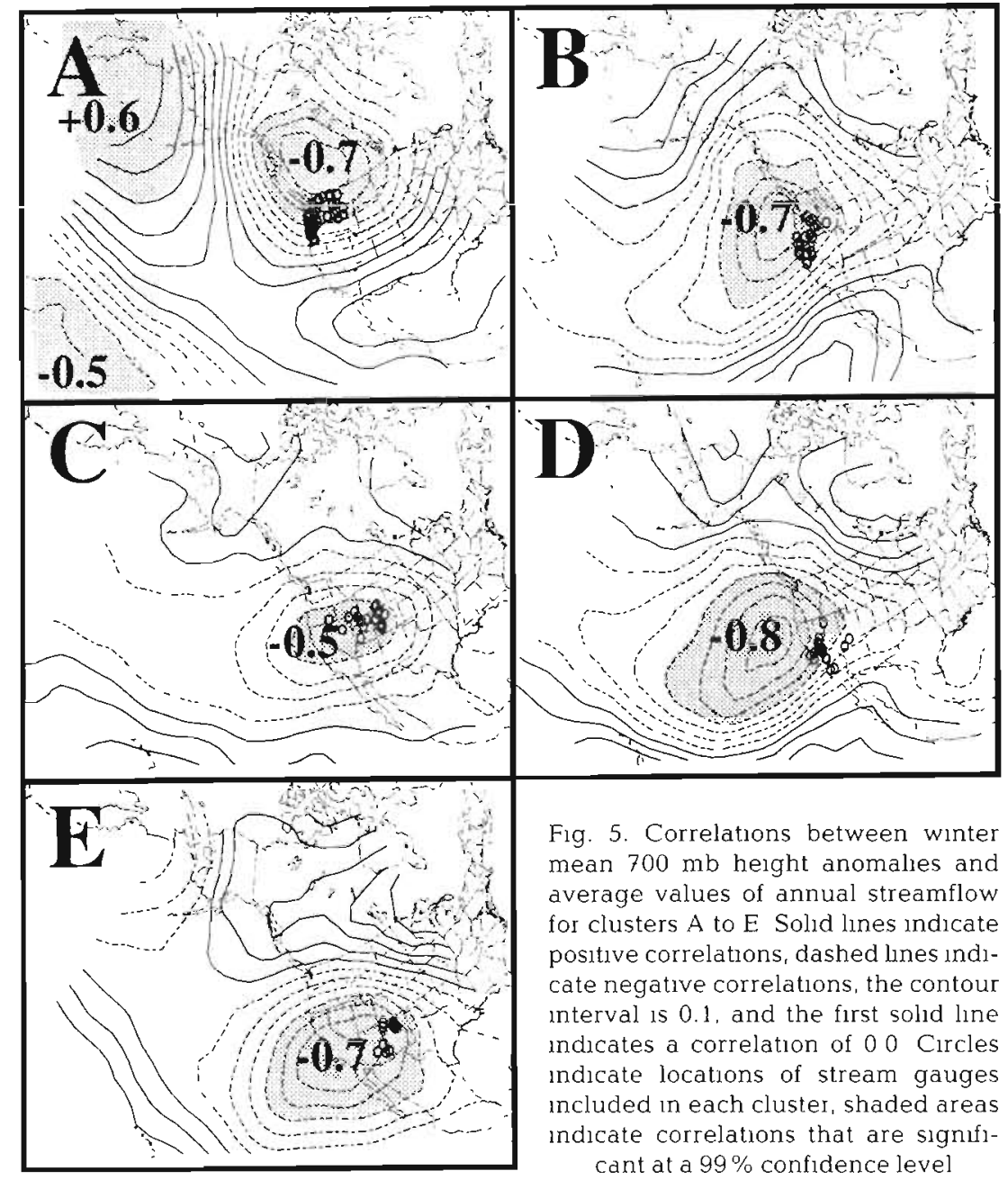


United States. The west-to-east orientation of the negative anomalies suggests the movement of storm systems from the eastern North Pacific Ocean into the central western United States. The correlation field for cluster $C$ is not as strong as are the fields for clusters $A$, $B, D$, and $E$. This is consistent with the findings of Cayan \& Peterson (1989), Klein et al. (1965), and Weare \& Hoeschele (1983) who found that in contrast to the west coast, a smaller fraction of the winter precipitation in the Rocky Mountains and the Great Basin could be explained by upper-level geopotential height anomalies. Winter precipitation in these areas is significantly affected by other factors such as topography, surface heating, and surface friction (Cayan \& Roads 1984).

The correlation field for cluster D has some similarities to the correlation fields for clusters B and C. Negative winter mean $700 \mathrm{mb}$ height anomalies are centered to the west of northern California and indicate an anomalous southwesterly flow over southern California. A similar pattern was identified by Klein \& Bloom (1987) for above-average winter precipitation in southern California.

The correlation field for cluster $E$ also has some similarities to the correlation fields for clusters $B, C$, and $D$, but the center of the winter mean $700 \mathrm{mb}$ height anomalies over the eastern North Pacific Ocean and the western United States indicated for cluster $E$ is located farther south and east than are the centers of negative anomalies for clusters B, C. and $D$ (Fig. 5E). The correlation field for cluster $E$ indicates that above-average annual streamflow for the stream gauges included in cluster $E$ is associated with negative winter mean $700 \mathrm{mb}$ height anomalies centered over southern California, that extend from the eastern North Pacific Ocean to the central United States. In general, the negative anomalies indicate a storm track that has been displaced to the south, as well as an anomalous southwesterly flow of air from the eastern North Pacific Ocean into the southwestern United States. Cayan \& Peterson (1989) also found that December through August streamflow in parts of the interior western United States was associated with a southerly displaced storm track that extended from the eastern North Pacific Ocean across the southern part of the western United States. The negative anomalies also indicate an anomalous southeasterly flow of air across the eastern most part of the western United States, possibly indicating a contribution of winter precipitation from the Gulf of Mexico. This relation also was identified by Klein et al. (1965), who also noted that winter precipitation in parts of the interior western United States was associated with air flow that had an anomalous easterly component.
The correlations between winter mean $700 \mathrm{mb}$ height anomalies and annual streamflow illustrated in Fig. 5 indicate statistically significant and physically meaningful relations. Fig. 5 illustrates that annual streamflow in the western United States generally is negatively correlated with winter mean $700 \mathrm{mb}$ height anomalies over the eastern North Pacific Ocean and/or the western United States. Fig. 5 also indicates that annual streamflow is sensitive to the relative location of the center of winter mean $700 \mathrm{mb}$ height anomalies over the eastern North Pacific Ocean and/or the western United States. For example, negative anomalies associated with above-average annual streamflow measured at stream gauges located in the northern part of the western United States are centered farther north than are the negative anomalies associated with above-average annual streamflow measured at locations in the southern part of the western United States. Cayan \& Peterson (1989) found similar results for relations between winter mean sea-level pressures and December through August streamflow in the western United States. Cayan \& Peterson (1989) also found streamflow in the western United States to be negatively correlated with winter mean atmospheric pressures over the eastern North Pacific Ocean and the western United States. In addition, they found that above-average December through August streamflow in the northwestern United States was associated with negative atmospheric pressure anomalies that were centered farther north than were atmospheric pressure anomalies associated with above-average December through August streamflow in California.

Klein \& Bloom (1987) performed a study of the relations between $700 \mathrm{mb}$ height anomalies and monthly precipitation at 60 climate divisions across the conterminous United States. As part of their study, Klein \& Bloom (1987) produced composite maps of $700 \mathrm{mb}$ height anomalies for above-and below-average winter precipitation frequencies in northern and southern California. The composites generated for these 2 extreme conditions in northern and southern California are similar to the $700 \mathrm{mb}$ height anomaly patterns found in this study for above-and below-average values of annual streamflow in the western United States (Fig 5). Klein \& Bloom (1987) found that above-average precipitation during winter months in northern and southern California was associated with negative $700 \mathrm{mb}$ height anomalies centered of the northwest coast of the United States. The anomalous cyclonic circulation is associated with an anomalous southwesterly flow of moist air from the eastern North Pacific Ocean into the western United States. In contrast, below-average precipitation during winters in northern and southern California is associated with positive $700 \mathrm{mb}$ height anomalies centered off the northwest 
coast of the United States. The anomalous anticyclonic circulation prevents the intrusion of moist air from the eastern North Pacific Ocean into the western United States.

The results of this study also are consistent with those obtained by Cayan et al. (1991) who examined the relations between $700 \mathrm{mb}$ height anomalies and winter precipitation in the Sierra Nevada in California. Forty years of precipitation and air temperature data for the months of November through March were used to classify each winter season into wet and warm, dry and warm, wet and cool, and dry and cool categories. Composite $700 \mathrm{mb}$ height anomaly maps then were constructed for each category. For both dry winter categories, positive $700 \mathrm{mb}$ height anomalies were present over the western United States. In contrast, for the 2 wet categories, negative $700 \mathrm{mb}$ height anomalies dominated the western United States.

More recently, McCabe (1994) examined the relations between winter mean $700 \mathrm{mb}$ height anomalies and April 1 snowpack accumulations in the Gunnison River basin in southwestern Colorado. Results indicated that below-average April 1 snowpack accumulations are primarily associated with positive winter mean $700 \mathrm{mb}$ height anomalies (anomalous anticyclonic circulation) over the western United States. Moist air from the eastern North Pacific Ocean is moved to the north of the western United States along

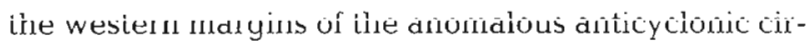
culation. In contrast, above-average April 1 snowpack accumulations are associated with negative winter mean $700 \mathrm{mb}$ height anomalies (anomalous cyclonic circulation) over the western United States and over most of the eastern North Pacific Ocean. McCabe (1994) also found that variations in winter mean $700 \mathrm{mb}$ heights explain over $50 \%$ of the variability in April 1 snowpack accumulations in the Gunnison River basin

The results of the correlation analyses are consistent with the findings of previous studies and indicate that annual streamflow in the western United States is significantly correlated with winter mean $700 \mathrm{mb}$ height anomalies over the eastern North Pacific Ocean and/or the western United States. These results also indicate that winter mean $700 \mathrm{mb}$ height anomalies over the eastern North Pacific Ocean and/or the western United States can be used to provide reliable estimates of temporal variations in annual streamflow.

\section{Long-term trends}

In a study of the relations between winter mean $700 \mathrm{mb}$ height anomalies and winter precipitation in the Sierra Nevada in California, Dettinger et al. (1993) identified long-term trends (1948 to 1992) in winter mean (January through March) $700 \mathrm{mb}$ height anomalies over the eastern North Pacific Ocean and the western United States. Their results indicate that winter mean $700 \mathrm{mb}$ height anomalies are decreasing over the eastern North Pacific Ocean and increasing over western Canada and the northwestern United States. Given these trends in winter mean $700 \mathrm{mb}$ height anomalies and the results presented in this paper, annual streamflow in the northwestern United States should indicate a decreasing trend as a result of the increasing trend in winter mean $700 \mathrm{mb}$ height anomalies over western Canada and the northwestern United States. Increases in winter mean $700 \mathrm{mb}$ height anomalies over western Canada and the northwestern United States indicate increased anomalous anticyclonic circulation in this area. Enhanced anomalous anticyclonic circulation over this area can affect annual streamflow in 2 ways: (1) anomalous anticyclonic circulation prevents the intrusion of moist air from the eastern North Pacific Ocean into the northwestern United States and thereby decreases precipitation, and (2) increased subsidence associated with anomalous anticyclonic circulation also decreases the opportunity for precipitation. To investigate this hypothesis, trends in winter mean $700 \mathrm{mb}$ height anomalies and annual streamflow for clusters $A$ to $E$ were computed by using Kendall's $\tau$ (Hirsch et al. 1962, Písss êt àl. 1986).

Similar to the study by Dettinger et al. (1993), the results of this analysis indicate a decreasing trend in winter mean $700 \mathrm{mb}$ anomalies in the eastern North Pacific Ocean and an increasing trend in winter mean $700 \mathrm{mb}$ height anomalies over western Canada and the northwestern United States (Fig. 6). The results also indicate a decreasing trend in annual streamflow (at a 95\% confidence level) for cluster $\mathrm{A}$, and an increasing trend in annual streamflow for cluster $E$. These results indicate a relation between the longterm increasing trend in winter mean $700 \mathrm{mb}$ height anomalies over western Canada and the northwestern United States and the long-term decreasing trend in annual streamflow in the northwestern United States (i.e. cluster A). The increasing trend in annual streamflow in the southeastern part of the western United States (i.e. cluster E) appears to be related to a decreasing trend in winter mean $700 \mathrm{mb}$ height anomalies over the south-central United States and the Gulf of Mexico. The decreasing trend in winter mean $700 \mathrm{mb}$ height anomalies over the south-central United States and the Gulf of Mexico indicates an increase in cyclonic circulation over this area which results in increased advection of moisture from the Gulf of Mexico into the southeastern part of the western United States. 


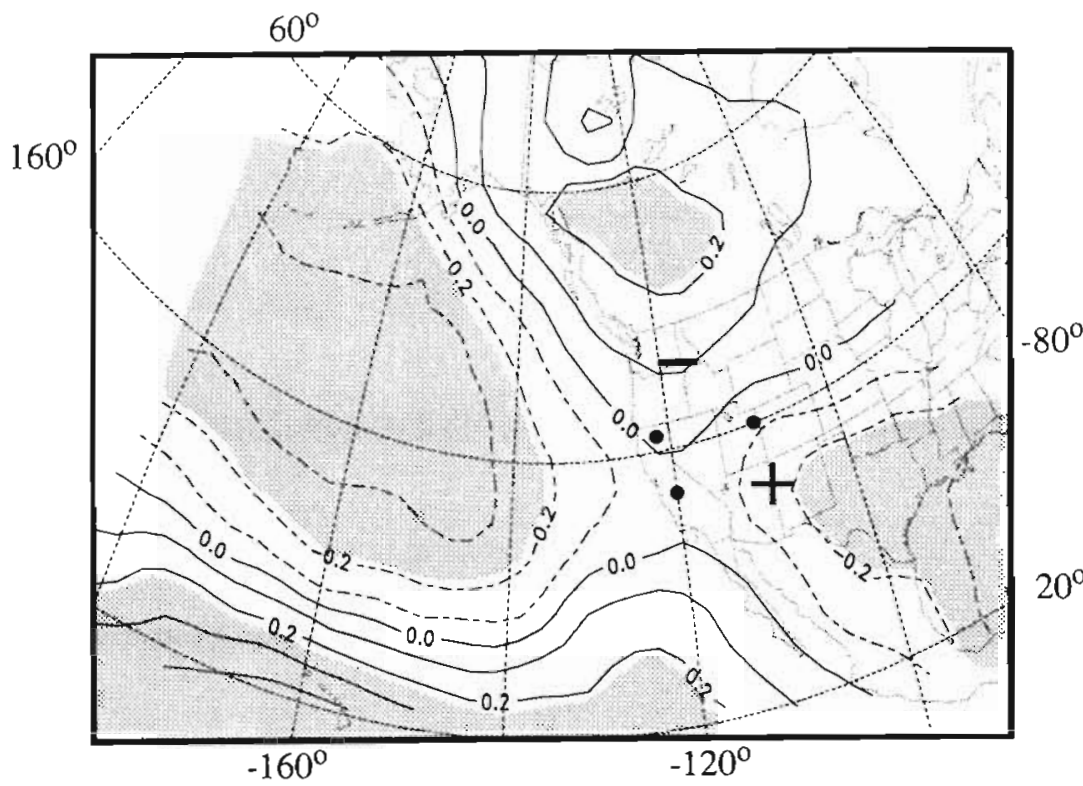

Fig 6. Trends in winter mean $700 \mathrm{mb}$ height anomalies for the winters 1948 through 1987 (indicated by values of Kendall's $\tau$ ) and trends in annual streamflow for clusters $A$ to E. Solid lines indicate positive values of Kendall's $\tau$ and increasing trends in winter mean $700 \mathrm{mb}$ height anomalies; dashed lines indicate negative values of Kendall's $\tau$ and decreasing trends in winter mean $700 \mathrm{mb}$ height anomalies; the contour interval is 0.1 Shaded areas indicate values of Kendall's $\tau$ that are statistically significant at a $95 \%$ confidence level. (t) clusters with increasing trends in annual streamflow significant at a $95 \%$ confidence level; (-) clusters with decreasing trends in annual streamflow signuficant at a $95 \%$ confidence level; ( clusters with non-significant trends in annual streamflow (symbols are near the geographical center of the respective cluster)

\section{Implications for the development of climate change scenarios}

Several studies have shown that GCM simulations of atmospheric circulation for current climatic conditions are reliable (Hay et al. 1992, Hewitson \& Crane 1992, McCabe \& Legates 1992), whereas GCM simulations of surface climatic vanables, such as temperature and precipitation, have been shown to be unreliable (Grotch \& MacCraken 1990). Hewitson \& Crane (1992) showed that the Goddard Institute for Space Studies (GISS) GCM effectively simulates the synoptic-scale circulation over North America. Hewitson \& Crane (1992) found that temporal and spatial distributions of GISS GCM simulations of sea-level pressures were statistıcally similar to temporal and spatial distributions of observed sea-level pressures. Simularly, McCabe \& Legates (1992) found that the Geophysical Fluid Dynamics Laboratory (GFDL) GCM, as well as the GISS GCM, simulated temporal and spatial sea-level pressure variability that is similar to that found in observed sea-level pressures. These studies indicate that GCMs reliably simulate important components of atmospheric circulation and synoptic-scale circulation patterns.

Because GCM simulations of atmosphenc circulation are more reliable than GCM simulations of temperature and precipitation, some researchers are developing empirical relations between observed temperature and precipitation and observed atmospheric circulation to translate GCM estimates of future atmosphenc circulation into estmmates of future temperature and precipitation (Yarnal \& Leathers 1988, Dettinger \& Cayan 1992, Hay et al. 1992, Zorita et al. 1992, Hewitson \& Crane 1993) Such empirical relations may pro- vide a scale-appropriate link between spatially coarse GCM simulations (100s of $\mathrm{km}$ ) and needed local- and regional-scale estimates of temperature and precipitation for studies of the environmental effects of climate change. Empincal relations between surface climate and atmospheric circulation may provide a realistic mechanism for describing the regional effects of climate change. Developing climate change scenarios in this manner assumes (1) that relations between atmosphenc circulation and surface climate variables are properly sumulated by GCMs, (2) that these relations will not change appreciably in a climate-changed world, and (3) that changes in surface climate in a climate-changed world primarily will be the result of changes in atmospheric circulation rather than in 'baselıne' mean conditions.

Currently, GCM estimates of streamflow do not agree as to the magnitude or direction of change from current to future climatic conditions. The simple linear relations presented in this paper clearly can be improved upon to develop more sophisticated models relating atmosphenc curculation and streamflow, however, these relations do explain a significant portion of the temporal varlability in annual streamflow in the western United States. Although many climatic factors other than winter mean atmospheric circulation affect annual streamflow in the western United States (e.g. the length of the snow season, the intensity, frequency, and path of storms, and local energy budgets), the use of the relations identified in this study with GCM estimates of winter mean $700 \mathrm{mb}$ height anomalies for future climatic conditions should at least indicate the general direction of change in annual streamflow in the western United States, which is an improvement over current GCM estimates. 


\section{CONCLUSIONS}

Winter mean $700 \mathrm{mb}$ height anomalies over the eastern North Pacific Ocean and/or the western United States were correlated with annual streamflow measured in the western United States. Results indicate that variability in winter mean $700 \mathrm{mb}$ height anomalies account for a statistically significant portion of the temporal variability in annual streamflow in the western United States. In general, above-average annual streamflow is associated with negative winter mean $700 \mathrm{mb}$ height anomalies over the eastern North Pacific Ocean and/or the western United States. These anomalies are indicative of anomalous cyclonic circulation which is associated with an anomalous flow of moist air from the eastern North Pacific Ocean into the western United States that increases winter precipitation and snowpack accumulations, and subsequently streamflow. Below-average annual streamflow is associated with positive winter mean $700 \mathrm{mb}$ height anomalies over the eastern North Pacific Ocean and/or the western United States. These positive anomalies indicate anomalous anticyclonic circulation which prevents the intrusion of moist air from the eastern North Pacific Ocean into the western United States, increases subsidence, decreases winter precipitation, and results in decreased streamflow. Results also indicate that long-term trends in annual streamflow are related to lung-tem teinds in winter meañ $700 \mathrm{mb}$ heighth añominalies.

\section{LITERATURE CITED}

Blackmon ML, Lee YH, Wallace JM, Hsu HH (1984) Time variation of $500 \mathrm{mb}$ height fluctuations with long, intermediate and short time scales as deduced from lag-correlation statistics. J atmos Sci 41:981-991

Bolin $\mathrm{B}$ (1986) How much $\mathrm{CO}_{2}$ will remain in the atmosphere? In: Bolin B, Doos BR, Jager J, Warrick R (eds) The greenhouse effect, climate change, and the ecosystem. John Wiley, New York, p 93-155

Cayan DR, Peterson DH (1989) The influence of North Pacific atmospheric circulation on streamflow in the West. In Peterson DH (ed) Aspects of climate variability in the Pacific and Western Americas. Geophysical Monograph 55. American Geophysical Union, Washington, DC, p $375-397$

Cayan DR, Riddle LG, Garen DC, Aguado E (1991) Winter climate variability and snowpack in the West. In: Redmond KT (ed) Pacific climate (PACLIM) workshop, March 10-13 1991. Program Technical Report 31. California Department of Water Resources Interagency Ecological Studies, Sacramento, p 125-134

Cayan DR, Roads JO (1984) Local relationships between United States west coast precipitation and monthly mean circulation parameters. Mon Weather Rev 112: 1276-1282

Dettinger MD, Cayan DR (1992) Climate-change scenarios for the Sierra-Nevada, California, based on winter atmos- pheric-circulation pattern. In: Proceedings, managing water resources during global change. American Water Resources Association, Bethesda, MD, p 681-690

Dettinger MD, Cayan DR, McCabe GJ (1993) Decadal trends in runoff over the western United States and links to persistent North Pacific sea-surface-temperature and atmospheric-circulation patterns. In: Proceedings of the 18th annual climate diagnostics workshop. US Department of Commerce, Washington, DC, p 240-243

Gammon RH, Sundquist ET, Fraser PJ (1985) History of carbon dioxide in the atmosphere. In: Trabalka JR (ed) Atmospheric carbon dioxide and the global carbon cycle US Department of Energy, Washington, DC, p 25-62

Gray DM, Male DH (1981) Handbook of snow. Pergamon Press, New York

Gleick PH (1987) Regional hydrologic consequences of increases in atmospheric $\mathrm{CO}_{2}$ and other trace gases. Clim Change 10:137-161

Grotch SL, MacCraken MC.(1990) The use of general circulation models to predict regional climatic change. J Clim 4:286-303

Hay LE, McCabe GJ, Wolock DM, Ayers MA (1992) Use of weather types to disaggregate general circulation model predictions. J geophys Res 97:2781-2790

Hewitson BC, Crane RG (1992) Regional climates in the GISS GCM: synoptic scale circulation. J Clim 5:1002-1011

Hewitson BC. Crane RG (1993) Large-scale atmospheric controls on local precipitation in tropical Mexico. Geophys Res Lett 19:1835-1838

Hirsch RM, Slack JR, Smith RA (1982) Techniques of trend analysis for monthly water quality data. Water Resour Res 18:107-121

Kahya E, Dracup JA (1993) U.S. streamflow patterns in relation to the El Nino/Southern Oscillation. Water Resour Res 29:2491-2503

Klein WH (1963) Specification of precipitation from the 700millibar circulation. Mon Weather Rev 91:527-536

Klein WH, Crockett CW, Andrews JF (1965) Objective prediction of daily precipitation and cloudiness. J geophys Res 70:801-813

Klein WH, Bloom HJ (1987) Specification of monthly precipitation over the United States from the surrounding $700 \mathrm{mb}$ height field. Mon Weather Rev 115:2118-2132

Knox JC (1984) Fluvial response to small scale climate changes. In: Costa JE, Fisher PJ (eds) Developments and applications of geomorphology. Springer-Verlag, Berlin, p 318-342

Knox JL, Lawford RG (1990) The relationship between Canadian prairie dry and wet months and circulation anomalies in the mid-troposphere. Atmosphere-Ocean 28:189-215

Leathers DJ, Yarnal B, Palecki MA (1991) The Pacific/North American teleconnection pattern and United States climate. part 1: regional temperature and precipitation associations. J Clim 4:517-528

Legates DR, Willmott CJ (1992) A comparison of GCM-simulated and observed mean January and July precipitation. Paleogeogr Paleoclimatol Paleoecol (Global Planet Change Sect) 97:345-363

Lettenmaier DP, Sheer DP (1991) Climatic sensitivity of California water resources. J Water Resour Plan Mgmt 117 $108-125$

Lins HF, Sundquist ET, Ager TA (1988) Information on selected climate and climate-change issues. US Geological Survey Open File Rep 88-718, Reston, VA

Madden RA (1979) Observations of large-scale traveling Rossby waves. Reviews Geophys Space Phys 17: 1935-1949 
McCabe GJ (1994) Relations between atmospheric circulation and snowpack in the Gunnison River basin, Colorado. J Hydrol 157:157-175

McCabe GJ, Legates DR (1992) General-circulation-model simulations of winter and summer sea-level pressures over North America. Int J Climatol 12:815-827

McCabe GJ, Legates DR (in press) Relations between atmospheric circulation and snowpack accumulations in the western United States. Int J Climatol

Muller RA, Wax CL (1977) A comparative synoptic climatic baseline for coastal Louisiana. Geosci Man 18:121-129

Namias J (1975) Northern hemisphere seasonal sea level pressure and anomaly charts 1947-1974, CalCOFI Atlas No. 22. Marine Life Research Program, Scripps Institute of Oceanography, La Jolla, CA

Namias J (1981) Teleconnections of $700 \mathrm{mb}$ height anomalies for the northern hemisphere, CalCOFI Atlas No. 29. Marine Life Research Program, Scripps Institute of Oceanography, La Jolla, CA

Press WH, Flannery BP, Teukolsky SA, Vetterling WT (1986) Numerical Recipes. Cambridge University Press, Cambridge

Redmond KT, Koch RW (1991) Surface climate and streamflow variability in the western United States and their relationship to large-scale circulation indices. Water Resour Res 27:2381-2399

Slack JR, Landwehr JM (1992) Hydro-climatic data network (HCDN): a U.S. Geological Survey streamflow data set for

Editor: V. Meentemeyer, Athens, Georgia, USA the United States for the study of climate variations 1874-1988. US Geological Survey Open File Report 92-129, Reston, VA

Stidd CK (1954) The use of correlation fields in relating precipitation to circulation. J Meteor ol 11:202-213

Wallace JM, Gutzler DS (1981) Teleconnections in the $500 \mathrm{mb}$ geopotential height field during northern hemisphere winter. Mon Weather Rev 109:784-812

Walsh JE, Richman MB, Allen DW (1982) Spatial coherence of monthly precipitation in the United States. Mon Weather Rev 110:272-286

Weare BC, Hoeschele MA (1983) Specification of monthly precipitation in the western United States from monthly mean circulation. J Clim appl Meteorol 22:1000-1007

Willmott CJ, Legates DR (1993) A comparison of GCM-simulated and observed mean January and July surface air temperature. J Climate 6:274-291

WMO (World Meteorological Organization) (1970) Guide to hydrometeorological practices. WMO-No 168.TP.82, Geneva

Yarnal B, Leathers DJ (1988) Relationships between interdecadal and interannual climatic variations and their effect on Pennsylvania climate. Annls Ass Am Geograph 78:624-641

Zorita E, Kharin V, von Storch H (1992) The atmospheric circulation and sea surface temperature in the North Atlantic area in winter: their interaction and relevance for Iberian precipitation. J Climate 5:1097-1108

Manuscript first received: September 15, 1994

Revised version accepted: December 21, 1994 